\title{
Different effects of maternal parity, cold exposure and nutrient restriction in late pregnancy on the abundance of mitochondrial proteins in the kidney, liver and lung of postnatal sheep
}

\author{
D P Yakubu, A Mostyn, V Wilson, S Pearce, M C Alves-Guerra ${ }^{1}$, C Pecqueur ${ }^{1}$, B Miroux ${ }^{1}$, H Budge, \\ T Stephenson and M E Symonds
}

Centre for Reproduction and Early Life, Institute of Clinical Research, University Hospital, Nottingham NG7 2UH, UK ${ }^{1}$ Faculté de Médecine Necker-Enfants-Malades, CNRS-UPR 907, 156, rue de Vaugirard, 75730 Paris Cedex 15, France

Correspondence should be addressed to M E Symonds, Academic Division of Child Health, School of Human Development, University Hospital, Nottingham NG7 2UH, UK; Email: michael.symonds@nottingham.ac.uk

\begin{abstract}
Adaptation to the extrauterine environment at birth relies upon the onset of postnatal function and increased metabolism in the lungs, liver and kidney, mediated partly by activation of mitochondrial proteins such as the voltage-dependent anion channel (VDAC), cytochrome $c$ and, in the lung only, uncoupling protein (UCP)2. The magnitude of adaptation is dependent on the maternal metabolic and endocrine environment. We, therefore, examined the influence of maternal cold exposure (MCE) induced by winter shearing of pregnant sheep in conjunction with nutrient restriction (NR; $\mathbf{5 0} \%$ reduction in maternal food intake from 110 days gestation up to term). The effect of parity was also examined, as the offspring of nulliparous mothers are growth restricted compared with multiparous offspring. All sheep were twin bearing. One twin was sampled after birth and its sibling at 30 days. In the lung, both MCE and maternal nulliparity enhanced UCP2 abundance. However, whilst VDAC abundance was decreased in both the offspring of nulliparous mothers and by NR, it was transiently raised by MCE. Kidney VDAC abundance was reduced by MCE and nulliparity, adaptations only influenced by NR in multiparous mothers. Cytochrome $c$ abundance was raised by MCE and by NR in multiparous controls and raised in offspring of nulliparous mothers. Liver VDAC and cytochrome $c$ abundance were transiently reduced by MCE and persistently lower in offspring of nulliparous mothers. In conclusion, changes in the maternal metabolic environment have marked tissue-specific effects on mitochondrial protein abundance in the lungs, liver and kidney that may be important in enabling the newborn to effectively adapt to the extrauterine environment.
\end{abstract}

Reproduction (2007) 133 1241-1252

\section{Introduction}

Postnatal survival of mammals is dependent on the newborn's ability to effectively adapt to the extrauterine environment. This process includes the establishment of independent breathing via the lungs as well as the ability to synthesise glucose in the liver and excrete metabolic waste products via the kidneys. Birth is, therefore, associated with a dramatic increase in metabolic activity of these tissues and concomitant up-regulation of mitochondrial protein abundance and function (Mostyn et al. 2004). A number of mitochondrial proteins are potentially involved in this process including uncoupling proteins (UCP) and the voltage-dependent anion channel (VDAC; Mostyn et al. 2003).

In the lung, the abundance of both UCP2 and VDAC increase around the time of birth, adaptations that are important in enabling the lung to adapt to the rapid influx of air and increase in its metabolic activity (Mostyn et al. 2003, Gnanalingham et al. 2005c). UCP2 is a member of the inner mitochondrial membrane carrier subfamily and is highly abundant in a range of tissues (Pecqueur et al. 2001, Rousset et al. 2003). Its function remains a subject of intense debate (Stuart et al. 2001) and it has postulated roles in energy balance (Buemann et al. 2001), reactive oxygen species production (Negre-Salvayre et al. 1997), apoptosis (Voehringer et al. 2000), and macrophagemediated immunity (Arsenijevic et al. 2000). UCP2 shares $56 \%$ homology with the brown adipose tissuespecific UCP1 (Erlanson- Albertsson 2003), whose abundance peaks at birth in the sheep and is then no longer detectable after 1 month of postnatal life (Clarke et al. 1997b). Both UCP2 mRNA and protein abundance are strongly influenced by the current and previous 
maternal nutritional experience in adipose tissue and lung of sheep (Mostyn et al. 2003, Gnanalingham et al. 2005a, 2005c), an adaptation mediated in part by changes in local glucocorticoid action (Gnanalingham et al. 2005a).

Although the abundance of both UCP2 and VDAC in the postnatal lung and adipose tissue are nutritionally regulated (Mostyn et al. 2003); it is currently not known if comparable adaptations for VDAC occur in the kidney and liver, tissues that do not possess UCP2. Its is also unknown whether mitochondrial protein abundance may be differentially regulated with respect to size at birth, as a result of changes in the maternal environment directly or from manipulating maternal food intake. In order to assess the relative contributions of size at birth and the maternal nutritional environment on the development of these mitochondrial proteins, the present study utilised the following two models of intrauterine growth manipulation, namely maternal parity and maternal cold exposure (MCE).

In contrast, to UCP2, VDAC is located in the outer mitochondrial membrane. It is an anion selective channel considered to be the main pathway for metabolite and ion diffusion (Colombini 1979) and may influence respiration by changes in the permeability of the outer mitochondrial membrane (McEnery et al. 1993). VDAC, along with other membrane proteins, is thought to be responsible for the release of cytochrome $c$ from the inter-membrane space, a process that has been implicated in the chain of events involved in apoptosis (Crompton 1999, Zalk et al. 2005). The exact tissue-specific location of these two mitochondrial proteins has yet to be fully established and was a further aim of the present study.

In summary, our study was designed to determine, first, the effect of maternal parity plus nutrition and any potential interaction between these two variables on the expression and the abundance of mitochondrial VDAC, cytochrome $c$ and/or UCP2 in the neonatal kidney, liver and lung. This was accompanied by a second study to investigate the effect of maternal chronic cold exposure induced by winter shearing during mid-pregnancy with nutrient restriction (NR) over the final month of gestation on the same mitochondrial proteins. Given that birth weight is lower in primiparous compared with multiparous mothers (Gardner et al. 2007) whereas it is increased by MCE (Symonds et al. 1992), it was hypothesised that maternal parity would attenuate the effects of NR on offspring mitochondrial protein abundance. In contrast, chronic MCE induced by winter shearing was hypothesised to overcome the negative effects of NR in late gestation on these mitochondrial proteins. Neonatal development, as determined by body size, organ weight and mitochondrial protein abundance was, therefore, examined at 1 and 30 days of postnatal life. This represents the period over which the newborn effectively adapts to the extrauterine environment and concomitantly establishes respiratory control, metabolic response to feeding and waste removal (Symonds et al. 1989a, 1992) and during which the kidney, liver and lung all have critical roles (Mellor \& Cockburn 1986).

\section{Materials and Methods}

\section{Study A: effects of maternal parity and NR}

Twenty-four (14 nulliparous and 10 multiparous), Border Leicester cross Swaledale sheep of similar body weight and condition score, and of known mating date, were entered into the study. In order to reduce the number of pregnant animals recruited into the study, and to minimise any potential confounding maternal influence on organ development, twin-bearing sheep were used. Following conception, animals were group-housed and fed daily a diet sufficient to fully meet their total metabolic requirements. All nulliparous sheep were 2 years old and had never been previously mated. The multiparous sheep were aged 3-4 years and had all experienced two previous successful pregnancies. This is important because there is little increase in birth weight after a second pregnancy (Gardner et al. 2007).

At 110 days gestation, i.e. 1 month prior to predicted date of birth, all animals were individually housed and randomly assigned to one of two nutrition groups. Six nulliparous and five multiparous mothers were allocated to the control (C) group, fed and consumed $100 \%$ of total metabolisable energy (ME) requirements for maternal body weight and stage of pregnancy, as described in detail by Mostyn et al. (2003). The remaining eight nulliparous and five multiparous mothers were nutrientrestricted, consuming $50 \%$ of total ME requirements until term. The diet comprised chopped hay and concentrate and was provided in a 3:1 weight ratio (Mostyn et al. 2003), with all animals having continual access to a mineral block and fresh water. At term, all offspring were delivered naturally with no intervention and birth weight recorded. One twin was randomly selected from each mother to be tissue sampled following humane euthanasia by an i.v. injection of barbiturate $(200 \mathrm{mg} / \mathrm{kg}$ pentobarbital sodium: Euthatal: RMB Animal Health, Dagenham, UK) within 6 h of birth. All mothers were housed with their remaining offspring and fed a diet of hay ad libitum, together with a fixed amount of concentrate sufficient to fully meet her own metabolisable requirements plus that required to maintain lactation. The second twin was therefore reared with its mother and, thus, was raised as a singleton until 30 days postnatal age when it was similarly tissue sampled. Again, each animal was euthanized, their organs rapidly dissected, weighed, a representative portion of each placed in liquid nitrogen and stored at $-80{ }^{\circ} \mathrm{C}$ until further analysis. In the case of the liver, this comprised the same area of the right lobe from each animal. All procedures were performed with the 
necessary institutional ethical approval as designated under the UK Animals (Scientific Procedures) Act, 1986.

\section{Study B: effects of MCE and NR}

Thirty-three twin-bearing multiparous Bluefaced Leicester crossed Swaledale sheep of similar body weight and condition score and of known mating date were group housed indoors under natural day light conditions at mid gestation (68 \pm 2 days) in December as previously described (Pearce et al. 2005). Fifteen were shorn (S; i.e. cold-exposed) at 70 days gestation and 18 remained unshorn $(U)$. These animals were further divided into control (C) and NR groups, at $115 \pm 2$ days, resulting in four groups: unshorn control (UC $n=9$ ), unshorn nutrient-restricted (UNR $n=9$ ), shorn control (SC $n=8$ ) and shorn nutrient-restricted (SNR $n=7$ ). The $C$ animals were fed straw ad libitum and a fixed amount of concentrate, which was calculated to sufficiently meet the ME requirements (in accordance to fetal number and stage of gestation), throughout the study. NR mothers again consumed $50 \%$ of this amount during the final 4 weeks of gestation (Agricultural Research Council 1980). After giving birth normally at term, all mothers and offspring were fed and sampled as described above for study A.

\section{Study C: tissue-specific histological location of VDAC and cytochrome $\mathrm{c}$}

In order to establish the cellular location of both VDAC and cytochrome $C$ within the kidney, liver and lung representative histological samples were taken from each tissue from both a late gestation fetus and an adult sheep $(n=4)$. This enabled us to determine whether the relative distribution of each protein differs with development. All sheep used for this analysis were fed the same diet as described above and each animal consumed sufficient feed to fully meet their total metabolic energy requirements. For each tissue, serial sections were prepared from paraffin-embedded tissue samples and immunocytochemistry for each protein performed using the same antibodies as described below at antiserum at a range of dilutions from 1:100 to 1:1000 using the same techniques as described by Dandrea et al. (2001). Following incubation with enzyme conjugated second antibody and chromogen substrate, sections were examined by light microscopy. The specificity of the procedure was confirmed by the absence of binding when adjacent sections were incubated with rabbit serum from an unimmunised rabbit in place of rabbit anti-ovine primary antibody. It was not able to perform the same analyses with respect to the location of UCP2 in the lung due to the lack of available antibodies (Gnanalingham et al. 2005f).

\section{Laboratory analyses}

\section{Protein detection}

Mitochondria were prepared from $0.5 \mathrm{~g}$ frozen tissue as described previously (Budge et al. 2000) and the protein concentration of each mitochondrial preparation, as well as the initial tissue homogenate, determined (Lowry et al. 1951) and used to calculate total organ protein. Western blotting was carried out to measure the abundance of VDAC, cytochrome $c$ and UCP2 in mitochondrial preparations. Ten micrograms of mitochondrial protein from each tissue was loaded onto a $12 \%$ SDS-polyacrylamide gel and subjected to electrophoresis. Proteins were then transferred to a nitrocellulose membrane by electroblotting. Densitometric analysis of Ponceau red staining of all membranes confirmed that equal amounts of protein were transferred before immunodetection (Mostyn et al. 2003). The abundance of VDAC abundance was determined using an antibody raised in rabbits to ovine VDAC (Mostyn et al. 2003) at a dilution of 1 in 2000. Abundance of cytochrome $C$ was determined using a commercial antibody (Santa Cruz, CA, USA) at a dilution of 1:1000 whilst UCP2 was measured (Mostyn et al. 2003), using the same antibody as described by Pecqueur et al. (2001) raised against human UCP2, at a dilution of 1:10 000 . Due to the very limited amount of this antibody available, it was only possible to determine UCP2 abundance in mitochondria prepared from lungs of 1-day old offspring. There are currently no other antibodies that are able to convincingly detect ovine UCP2 (Gnanalingham et al. 2005f). Specificity of detection was confirmed using non-immune rabbit serum. All gels were run in duplicate and included a range of molecular weight markers and an appropriate reference sample. For the liver and kidney, this reference was an ovine mitochondrial protein sample from a newborn sheep born to a multiparous well-fed mother whilst for UCP2, the peptide to which the antibody was raised against was used. Densitometric analysis for VDAC detection was performed on each gel following image detection using a Fujifilm LAS-1000 cooled CCD camera (Fuji Photo Film Co. Ltd, Tokyo, Japan) and all values were expressed in densitometric units.

\section{Dry weight analysis}

Lung dry weights were determined by freeze-drying a representative portion of each tissue.

\section{Statistical analyses}

Data were first subjected to a Kolmogorov-Smirnov normality test. As data were found to conform to a normal distribution, parametric statistical tests were performed. Separate statistical analysis with respect to the effects between the groups of parity and NR or cold exposure and 
NR were carried out using a general linear model test (GLM). Mean organ weight and mitochondrial protein abundance were each analysed using a univariate GLM test to investigate the independent effect of parity (or cold exposure), late gestational NR and potential parity (or cold exposure) $\times$ diet interactions. A statistically significant difference was inferred by $P<0.05$. All statistical analyses were performed using SPSS (Chicago, Illinois, USA) software package (version 11.0). Results are presented as means with their standard errors.

\section{Results}

\section{Study A: effect of maternal parity and NR}

Birth weight was reduced $(P<0.001)$ in the offspring of nulliparous mothers, irrespective of maternal NR (Nulliparous C: $4.26 \pm 0.2$; Nulliparous NR: $3.54 \pm 0.1$; Multiparious C: $4.73 \pm 0.2$; Multiparious NR: $4.51 \pm 0.3 \mathrm{~kg}$ ). By 1 month age, there was no difference in body weights between parity groups but offspring born to nutrientrestricted mothers weighed less $(P<0.05$; Nulliparous $C$ : 16.4 \pm 1.4 ; Nulliparous NR: $14.3 \pm 0.7$; Multiparious C: $17.2 \pm 1.0$; Multiparious NR: $14.9 \pm 0.4 \mathrm{~kg}$ ).

\section{The lung}

At 30 , but not 1 day of age, lung fresh and dry and relative weights, were lower in offspring of nulliparous mothers and mitochondrial protein content was raised, whereas lung protein content was lower at 1 and 30 days of age (Tables 1 and 2). Irrespective of parity, maternal NR caused a significant decrease in lung fresh, but not relative, weight, at 1 but not 30 days of age. With respect to the abundance of individual mitochondrial proteins at 1 and 30 days of age, VDAC was significantly lower whilst cytochrome $c$ abundance was raised in the lungs of offspring born to control nulliparous mothers (Fig. 1). This latter adaptation was abolished by maternal NR, but only at 1 day of age. UCP2 abundance was also increased at 1 day of age in offspring of nulliparous mothers, irrespective of maternal food intake. Maternal NR caused a significant decrease in the abundance of VDAC, but not UCP2 (Fig. 1), at 1 day of age. Cytochrome $c$ abundance was persistently reduced by maternal NR in offspring of nulliparous, but not multiparous mothers. By 30 days of age, therefore, cytochrome $c$ abundance was modestly up-regulated by NR in offspring born to multiparous mothers. At this age, the abundance of VDAC was increased by maternal NR regardless of parity.

\section{The kidney}

At 1 day of age mitochondrial protein content was significantly lower in offspring of nulliparous mothers (Table 1). This was accompanied by a reduced total, but not relative, kidney weight although this was only significantly different between NR offspring. By 30 days of age, total and relative kidney weights were lower in offspring born to nulliparous mothers (Table 2), when protein but not mitochondrial protein content was lower in control, but not NR, offspring. The abundance of VDAC was significantly decreased, whilst cytochrome $c$ was increased in kidneys of offspring from nulliparous compared with multiparous mothers at both 1 and 30 days of age (Fig. 2). This effect on cytochrome $c$ was prevented by maternal NR which resulted in a persistent decreased abundance in the kidneys of the offspring of control-fed mothers. In contrast, maternal NR was accompanied by raised cytochrome $c$ abundance in offspring of multiparous mothers at 1 day of age, compared with a decrease at 30 days. NR also caused a reduction in VDAC abundance in offspring of multiparous mothers at both 1 and 30 days of age.

Table $1 \mathrm{Effect}$ of maternal parity and nutrient restriction on organ weight, total protein and mitochondrial protein contents on day 1 of postnatal life.

\begin{tabular}{|c|c|c|c|c|c|}
\hline & & \multicolumn{2}{|c|}{ Nulliparous } & \multicolumn{2}{|c|}{ Multiparous } \\
\hline & & $\mathrm{C}(n=7)$ & $\mathrm{NR}(n=7)$ & $\mathrm{C}(n=5)$ & $\mathrm{NR}(n=5)$ \\
\hline \multirow[t]{5}{*}{ Lung } & Fresh weight (g) & $92 \pm 2.0$ & $76 \pm 2.3^{*}$ & $102 \pm 10.1$ & $83 \pm 9.6^{*}$ \\
\hline & Lung:bodyweight ratio & $20.6 \pm 3.9$ & $18.7 \pm 3.0$ & $20.1 \pm 4.7$ & $17.8 \pm 3.7$ \\
\hline & Dry weight (g) & $19.5 \pm 0.6$ & $16.1 \pm 0.6$ & $18.0 \pm 1.5$ & $16.9 \pm 1.2$ \\
\hline & Total protein (g) & $8.1 \pm 0.8^{\mathrm{a}}$ & $6.9 \pm 0.5^{\mathrm{a}}$ & $13.0 \pm 1.4^{\mathrm{b}}$ & $10.4 \pm 1.2^{\mathrm{b}}$ \\
\hline & Mitochondrial protein (g) & $0.91 \pm 0.36$ & $0.65 \pm 0.11$ & $1.08 \pm 0.12$ & $0.86 \pm 0.08$ \\
\hline \multirow[t]{4}{*}{ Kidney } & Weight (g) & $11.8 \pm 1.2$ & $9.4 \pm 0.6^{* a}$ & $13.7 \pm 1.6$ & $11.5 \pm 0.6^{* b}$ \\
\hline & Kidney:bodyweight ratio & $2.8 \pm 0.1$ & $2.8 \pm 0.1$ & $2.9 \pm 0.1$ & $2.7 \pm 0.1$ \\
\hline & Total protein $(\mathrm{g})$ & $2.92 \pm 0.9$ & $2.97 \pm 0.3$ & $2.89 \pm 0.2$ & $2.29 \pm 0.1$ \\
\hline & Mitochondrial protein (g) & $0.15 \pm 0.01^{\mathrm{a}}$ & $0.16 \pm 0.01^{\mathrm{a}}$ & $0.28 \pm 0.02^{b}$ & $0.24 \pm 0.02^{b}$ \\
\hline \multirow[t]{4}{*}{ Liver } & Weight (g) & $85 \pm 7.7^{\mathrm{a}}$ & $73 \pm 3.6^{\mathrm{a}}$ & $110 \pm 11.3^{b}$ & $92 \pm 4.6^{\mathrm{b}}$ \\
\hline & Liver:bodyweight ratio & $19.7 \pm 2.1$ & $20.8 \pm 1.8$ & $24.1 \pm 3.3$ & $20.4 \pm 2.7$ \\
\hline & Total protein $(\mathrm{g})$ & $22.3 \pm 2.6^{\mathrm{a}}$ & $20.8 \pm 1.4^{\mathrm{a}}$ & $34.1 \pm 4.8^{\mathrm{b}}$ & $28.1 \pm 1.9^{b}$ \\
\hline & Mitochondrial protein (g) & $0.83 \pm 0.1^{\mathrm{a}}$ & $0.95 \pm 0.1^{\mathrm{a}}$ & $1.92 \pm 0.4^{\mathrm{b}}$ & $1.52 \pm 0.1^{b}$ \\
\hline
\end{tabular}

Organs were sampled from offspring born to nulliparous or multiparous sheep that consumed either $100 \%$ (controls, C ( $n=5-7)$ ) or $50 \%$ (nutrientrestricted, NR $(n=5-7)$ ) of total metabolisable energy requirements to maintain maternal metabolism and fetal growth between 110 days gestation and term. Values are means \pm s.E.M.; * denotes a significant effect of NR; whilst different superscript letters denote statistically significant differences between nulliparous and multiparous groups; $P<0.05$. 
Table 2 Effect of maternal parity and nutrient restriction on organ weight, total protein and mitochondrial protein contents on day 30 of postnatal life.

\begin{tabular}{|c|c|c|c|c|c|}
\hline & & \multicolumn{2}{|c|}{ Nulliparous } & \multicolumn{2}{|c|}{ Multiparous } \\
\hline & & $\mathrm{C}(n=7)$ & $\mathrm{NR}(n=7)$ & $\mathrm{C}(n=5)$ & $\mathrm{NR}(n=5)$ \\
\hline \multirow[t]{5}{*}{ Lung } & Fresh weight $(\mathrm{g})$ & $187 \pm 34.3^{\mathrm{a}}$ & $160 \pm 19.1^{\mathrm{a}}$ & $295 \pm 16.5^{b}$ & $232 \pm 6.3^{b}$ \\
\hline & Lung:bodyweight ratio & $12.4 \pm 3.6^{\mathrm{a}}$ & $11.5 \pm 4.3^{\mathrm{a}}$ & $17.2 \pm 0.9^{\mathrm{b}}$ & $15.6 \pm 1.2^{\mathrm{b}}$ \\
\hline & Dry weight (g) & $36.3 \pm 7.8^{\mathrm{a}}$ & $31.5 \pm 3.9^{\mathrm{a}}$ & $52.3 \pm 3.7^{\mathrm{b}}$ & $50.8 \pm 2.0^{\mathrm{b}}$ \\
\hline & Total protein (g) & $19.3 \pm 1.2^{\mathrm{a}}$ & $18.2 \pm 1.1^{\mathrm{a}}$ & $37.4 \pm 2.0^{\mathrm{b}}$ & $28.1 \pm 1.3^{\mathrm{b}}$ \\
\hline & Mitochondrial protein $(\mathrm{g})$ & $1.25 \pm 0.1^{\mathrm{a}}$ & $0.88 \pm 0.2^{\mathrm{a}}$ & $0.59 \pm 0.1^{b}$ & $0.64 \pm 0.1^{b}$ \\
\hline \multirow[t]{4}{*}{ Kidney } & Weight $(\mathrm{g})$ & $31 \pm 2.2^{\mathrm{a}}$ & $29 \pm 1.2^{\mathrm{a}}$ & $45 \pm 1.7^{\mathrm{b}}$ & $36 \pm 1.2^{\mathrm{b}}$ \\
\hline & Kidney:bodyweight ratio & $2.0 \pm 0.1^{\mathrm{a}}$ & $2.0 \pm 0.1^{\mathrm{a}}$ & $2.6 \pm 0.2^{\mathrm{b}}$ & $2.4 \pm 0.1^{\mathrm{b}}$ \\
\hline & Total protein $(\mathrm{g})$ & $8.9 \pm 0.7^{\mathrm{a}}$ & $9.1 \pm 0.2$ & $11.0 \pm 0.4^{\mathrm{b}}$ & $9.1 \pm 0.5$ \\
\hline & Mitochondrial protein (g) & $1.78 \pm 0.1$ & $1.82 \pm 0.1$ & $2.12 \pm 0.2$ & $1.77 \pm 0.1$ \\
\hline \multirow{4}{*}{ Liver } & Weight (g) & $260 \pm 8.3^{\mathrm{a}}$ & $265 \pm 10.6^{a}$ & $410 \pm 20.7^{b}$ & $369 \pm 14.7^{b}$ \\
\hline & Liver:bodyweight ratio & $15.6 \pm 2.5^{\mathrm{a}}$ & $18.4 \pm 3.0^{\mathrm{a}}$ & $24.5 \pm 1.5^{\mathrm{b}}$ & $24.9 \pm 2.7^{\mathrm{b}}$ \\
\hline & Total protein $(\mathrm{g})$ & $84 \pm 8.9^{\mathrm{a}}$ & $79 \pm 4.0^{\mathrm{a}}$ & $120 \pm 8.3^{\mathrm{b}}$ & $109 \pm 4.8^{\mathrm{b}}$ \\
\hline & Mitochondrial protein $(\mathrm{g})$ & $4.0 \pm 0.25^{\mathrm{a}}$ & $4.2 \pm 0.14^{\mathrm{a}}$ & $6.6 \pm 0.50^{b}$ & $5.4 \pm 0.66^{\mathrm{b}}$ \\
\hline
\end{tabular}

Organs were sampled from offspring born to nulliparous or multiparous sheep that consumed either $100 \%$ (controls, C ( $n=5-7)$ ) or $50 \%$ (nutrientrestricted, NR $(n=5-7)$ ) of total metabolisable energy requirements to maintain maternal metabolism and fetal growth between 110 days gestation and term. Values are means \pm s.E.M.; *denotes a significant effect of NR; whilst different superscript letters denote statistically significant differences between nulliparous and multiparous groups; $P<0.05$.

\section{The liver}

Irrespective of postnatal age, total liver weight, plus its protein and mitochondrial protein contents were all lower in offspring of nulliparous compared with multiparous offspring (Tables 1 and 2), and was accompanied with a significant decrease in VDAC and cytochrome $c$ abundance (Fig. 3). Relative liver weights were only reduced in offspring of nulliparous mothers at 30 days of age. Maternal NR had no effect on liver weight or composition. In offspring born to nulliparous mothers, VDAC abundance was increased by NR at 1 but not 30 days of age. Cytochrome $c$ abundance was decreased by NR in livers of multiparous offspring at 30 days of age only.

\section{Study B: effect of MCE and NR}

Birth weight was increased $(P<0.05)$ by MCE, an effect blocked by NR (UC: $4.64 \pm 0.29$; UNR: $4.28 \pm 0.23$; SC: $5.51 \pm 0.32$; SNR: $4.06 \pm 0.21 \mathrm{~kg}$ ). By 1 month age there was no effect of either MCE or NR on whole body weights (UC: $16.0 \pm 0.8$; UNR: $14.8 \pm 0.6$; SC: $17.3 \pm$ 0.7 ; SNR: $16.7 \pm 0.7 \mathrm{~kg}$ ).

\section{The lung}

Fresh and dry lung weights were unaffected by MCE but at 1 day of age only fresh weight was reduced in NR offspring in conjunction with a lower mitochondrial protein content (Tables 3 and 4). Total mitochondrial protein content was also decreased at 1 day of age in the lungs of offspring born to cold-exposed mothers, whereas the abundance of both $\mathrm{UCP} 2$ and VDAC were raised, although the latter effect was blocked by maternal NR (Fig. 4). Cytochrome $c$ abundance was unaffected at this age. By 1 month of age, MCE and NR caused a significant increase in VDAC, whereas the rise in cytochrome $c$ abundance with MCE was not seen in NR offspring.

\section{The kidney}

At 1 day of age MCE had no effect on kidney weight but caused a significant increase in protein but not mitochondrial protein content (Table 3). This response was prevented by maternal NR. By 1 month of age both total and relative kidney weight, but not protein content was increased by MCE, a response not seen in nutrientrestricted offspring. Maternal NR resulted in a significant reduction in total protein content of the kidney at 1 day of age only. The abundance of VDAC was reduced in the kidneys of offspring born to cold-exposed mothers at 1 and 30 days of age (Fig. 5). At 1 day of age, only, kidneys of offspring born to NR mothers had a lower abundance of VDAC irrespective of MCE. The abundance of cytochrome $c$ was increased in the kidneys of offspring born to cold-exposed mothers at 1 day of age. By 30 days of age, its abundance was lower in offspring born to cold-exposed mothers in which no effect of NR was seen. However, in controls, at this age previous maternal NR resulted in a lower cytochrome $c$ abundance.

\section{The liver}

MCE had no effect on liver weight (or composition) that was reduced in NR offspring, in conjunction with a lower total protein and mitochondrial protein contents only at 1 day of age (Table 3 ). The abundance of both VDAC and cytochrome $c$ were both significantly reduced in coldexposed offspring at 1 day of age but in all groups were unaffected by maternal NR (Fig. 6). By 1 month of age, total (but not relative) liver weight was increased in the offspring of cold-exposed mothers (Table 4). At this age in offspring of mothers fed to requirements hepatic abundance of both VDAC and cytochrome $c$ were 

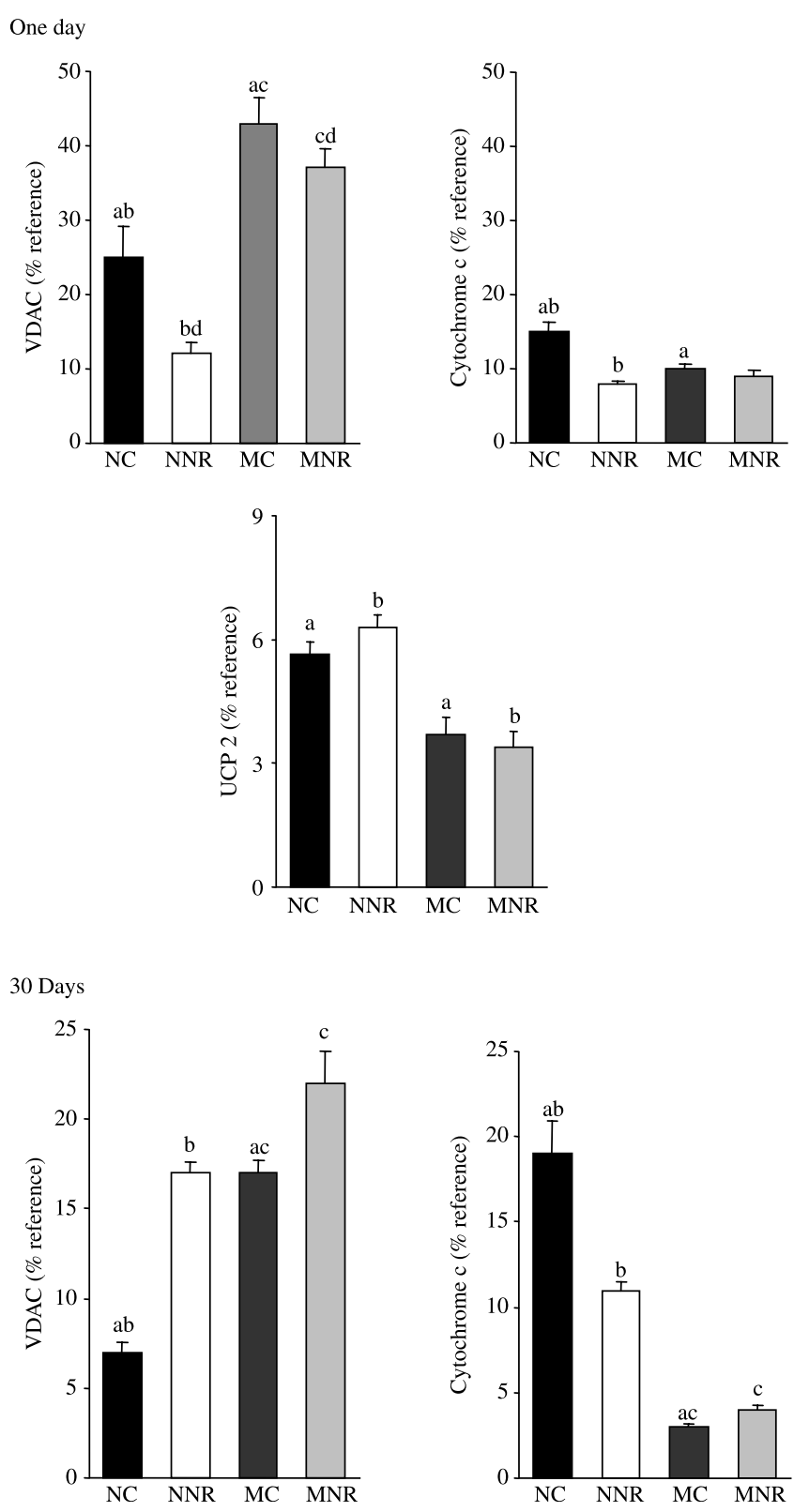

Figure 1 Effects of maternal parity and nutrient restriction during late gestation on the abundance of the mitochondrial proteins voltagedependent anion channel (VDAC), cytochrome $c$ and uncoupling protein (UCP)2 in the postnatal sheep lung. Mitochondria were prepared from lungs sampled from 1- or 30-day-old offspring born to nulliparous $(\mathrm{N})$ and multiparous $(\mathrm{M})$ sheep that consumed either $100 \%$ (controls, C) or $50 \%$ (nutrient-restricted, NR) of total metabolisable energy requirements to maintain maternal metabolism and fetal growth between 110 days gestation and term. Values are means with their standard errors; $n=5-7$ per group and the same superscript letters denote statistically significant differences between groups, $P<0.05$.

significantly increased by MCE (Fig. 6). With respect to cytochrome $c$, the same adaptation was observed in offspring born to mothers that were cold-exposed and nutrient-restricted. The abundance of VDAC was also reduced by a combination of MCE and NR.
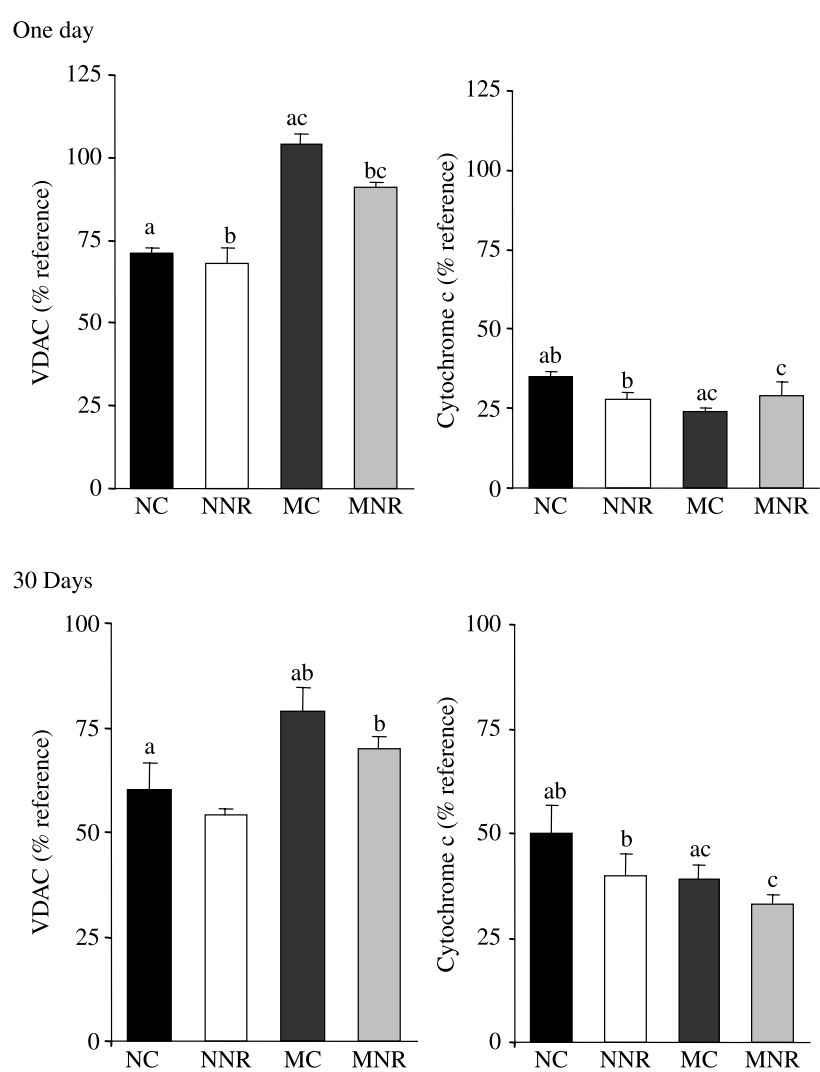

Figure 2 Effects of maternal parity and nutrient restriction during late gestation on the abundance of the mitochondrial proteins voltagedependent anion channel (VDAC) and cytochrome $c$ in the postnatal sheep kidney. Mitochondria were prepared from kidneys sampled from 1- or 30-day-old offspring born to nulliparous $(\mathrm{N})$ and multiparous $(\mathrm{M})$ sheep that consumed either $100 \%$ (controls, C) or $50 \%$ (nutrientrestricted, NR) of total metabolisable energy requirements to maintain maternal metabolism and fetal growth between 110 days gestation and term. Values are means with their standard errors; $n=5-7$ per group and the same superscript letters denote statistically significant differences between groups, $P<0.05$.

\section{Study C: tissue-specific histological location of VDAC and cytochrome $\mathrm{c}$}

There was no difference in the cellular location for either mitochondrial protein between the late gestational fetus and adult sheep so representative images for each tissue from the adult animal are only illustrated. In the kidney, both VDAC and cytochrome $c$ were co-localised to the renal tubules (see example for cytochrome $c$ in Fig. 7a). For the liver, these proteins were both co-localised within the epithelial lining (see example for cytochrome $c$ in Fig. 7b). With respect to the lung, VDAC was localised within the alveoli, whereas cytochrome $c$ was confined to the bronchioles (Fig. 7c).

\section{Discussion}

Our study reveals for the first time the pronounced effects that manipulating organ growth in the fetus as a 

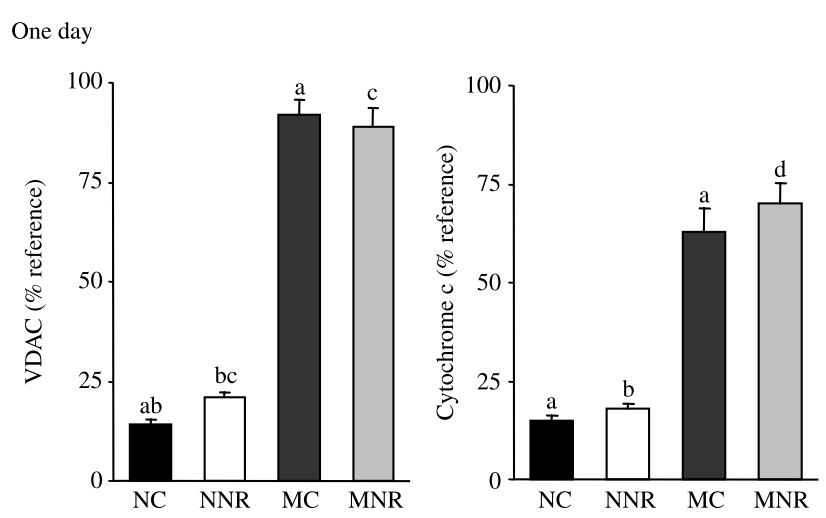

30 Days
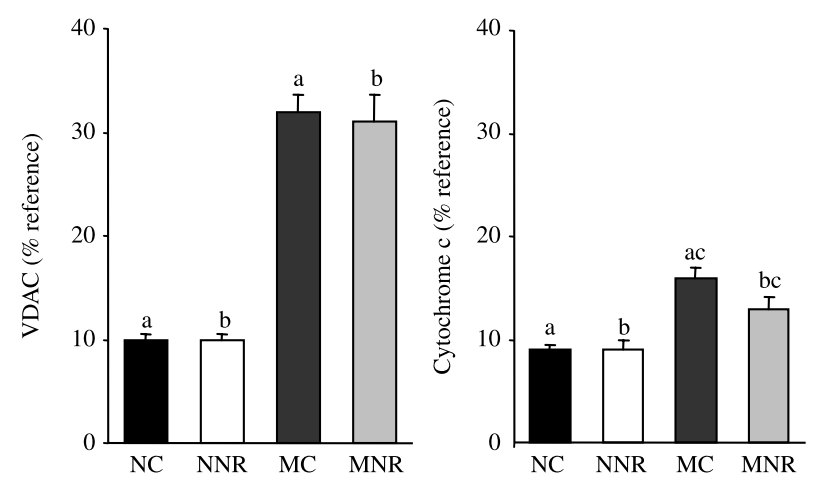

Figure 3 Effects of maternal parity and nutrient restriction during late gestation on the abundance of the mitochondrial proteins voltagedependent anion channel (VDAC) and cytochrome $c$ in the postnatal sheep liver. Mitochondria were prepared from livers sampled from 1- or 30-day-old offspring born to nulliparous $(\mathrm{N})$ and multiparous $(\mathrm{M})$ sheep that consumed either $100 \%$ (controls, C) or 50\% (nutrient-restricted, $\mathrm{NR}$ ) of total metabolisable energy requirements to maintain maternal metabolism and fetal growth between 110 days gestation and term. Values are means with their standard errors; $n=5-7$ per group and the same superscript letters denote statistically significant differences between groups, $P<0.01$.

consequence of differences in the maternal environment, caused by either maternal parity or cold exposure, on the abundance of the mitochondrial proteins VDAC and cytochrome $c$ in kidney, liver and lung and for UCP2 in the lung. Notably, both maternal parity and cold exposure had similar effects on mitochondrial protein abundance despite having opposite effects on birth weight. At the same time, reducing maternal food intake by half over the final month of gestation had only modest effects that were unrelated to the effects of maternal parity and cold exposure on individual organ weights.

\section{The lung}

It has recently been established that UCP2 mRNA and protein abundance both peak around the time of birth and may, therefore, have an important role in enabling the lung to effectively adapt to the rapid influx of cold air after commencing breathing (Gnanalingham et al. 2005c). An increased abundance of UCP2 in the lungs of offspring of nulliparous and cold-exposed mothers is suggestive of a positive adaptation that is likely to be mediated by changes in the maternal metabolic and hormonal environment through pregnancy. Interestingly, any adaptation of this kind was not dependent on maternal food intake per se as increased UCP2 was maintained in offspring born to NR mothers. Indeed, we have previously shown that maternal NR results in a persistent up-regulation of both UCP2 mRNA and protein (Mostyn et al. 2003, Gnanalingham et al. 2005c) although, in the present study, we were not able to determine protein abundance in lungs sampled from 30-day-old offspring due to insufficient antibody availability. The effect of MCE on UCP2 in the lung is the opposite of the response of the brown adipose tissuespecific UCP1, which has been shown to be downregulated (Pearce et al. 2005).

Both thyroid hormones and glucocorticoids are known to have critical roles in promoting mitochondrial protein abundance in preparation for life after birth (Symonds 1995, Fowden et al. 1998) and are, therefore, likely to be important in mediating the observed adaptations in UCP2 (Gnanalingham et al. 2005d). Indeed, potential glucocorticoid and thyroid response elements have been identified in the promoter region of human UCP2 (Tu et al. 1999). It is known that plasma thyroid hormones, but not cortisol concentrations, are increased in newborn offspring of cold-exposed mothers (Symonds et al. 1992, 1995). However, cortisol appears to be more important than thyroid hormones in promoting UCP2 mRNA and VDAC abundance during fetal compromise (Gnanalingham et al. 2005e). In this regard, in the fetal, newborn and juvenile sheep lung glucocorticoid receptor and UCP2 mRNA abundance are positively correlated (Gnanalingham et al. 2005c). At the same time triiodothyronine administration up-regulates lung UCP2 mRNA abundance $6 \mathrm{~h}$ after birth in rat pups, whereas the anti-thyroid drug, propylthiouracil, partially blocks this effect, responses that may be mediated through changes in non-esterified fatty acids (Xiao et al. 2004). Clearly, further studies are needed to examine the relative roles of both cortisol and thyroid hormones in the newborn of species born with a mature hypothalamic-pituitary axis.

Increased UCP2 in the lungs from offspring born to both nulliparous and cold-exposed mothers was not accompanied by parallel changes in VDAC abundance. The localisation of UCP2 within the lung has yet to be established but we have shown that VDAC is localised within the alveoli. One interpretation of our finding that the lungs of offspring of nulliparous mothers exhibited persistently lower VDAC abundance is that this could be specifically related to differences in lung alveolarisation. All offspring, with the exception of those born to NR nulliparous mothers, exhibited the expected decrease in VDAC abundance within the lung with postnatal age 
Table 3 Effect of maternal cold exposure and nutrient restriction on organ weight, total protein and mitochondrial protein on day 1 of postnatal life.

\begin{tabular}{|c|c|c|c|c|c|}
\hline & & \multicolumn{2}{|c|}{ Unshorn } & \multicolumn{2}{|c|}{ Shorn } \\
\hline & & $C(n=9)$ & $\mathrm{NR}(n=9)$ & $\mathrm{C}(n=7)$ & $\mathrm{NR}(n=7)$ \\
\hline \multirow[t]{5}{*}{ Lung } & Fresh weight (g) & $105 \pm 12.0$ & $80 \pm 7.1^{*}$ & $91 \pm 3.3$ & $74 \pm 4.0^{*}$ \\
\hline & Lung:bodyweight ratio & $22.2 \pm 2.4$ & $18.1 \pm 0.9$ & $18.1 \pm 1.2$ & $18.8 \pm 0.6$ \\
\hline & Dry weight (g) & $19.0 \pm 1.8$ & $16.0 \pm 1.2$ & $20.0 \pm 1.4$ & $16.0 \pm 0.8$ \\
\hline & Total protein (g) & $13.70 \pm 1.5$ & $10.00 \pm 1.0$ & $11.63 \pm 0.7$ & $8.54 \pm 0.5$ \\
\hline & Mitochondrial protein (g) & $1.13 \pm 0.12^{\mathrm{a}}$ & $0.82 \pm 0.06^{* a}$ & $0.80 \pm 0.10^{b}$ & $0.67 \pm 0.05^{b}$ \\
\hline \multirow[t]{4}{*}{ Kidney } & Weight (g) & $14 \pm 1.0$ & $12 \pm 0.7$ & $16 \pm 1.1$ & $11 \pm 0.5$ \\
\hline & Kidney:bodyweight ratio & $2.8 \pm 0.1$ & $2.8 \pm 0.1$ & $2.8 \pm 0.1$ & $2.7 \pm 0.1$ \\
\hline & Total protein $(\mathrm{g})$ & $2.9 \pm 0.2^{\mathrm{a}}$ & $2.4 \pm 0.1^{*}$ & $3.8 \pm 0.5^{\mathrm{b}}$ & $2.7 \pm 0.2^{*}$ \\
\hline & Mitochondrial protein (g) & $0.29 \pm 0.02$ & $0.25 \pm 0.02$ & $0.35 \pm 0.03$ & $0.25 \pm 0.01$ \\
\hline \multirow{4}{*}{ Liver } & Weight (g) & $120 \pm 10.3$ & $86 \pm 5.7^{*}$ & $118 \pm 3.4$ & $74 \pm 4.2^{*}$ \\
\hline & Liver:bodyweight ratio & $23.4 \pm 1.0$ & $20.6 \pm 1.3^{*}$ & $23.1 \pm 0.9$ & $20.1 \pm 1.0^{*}$ \\
\hline & Total protein $(\mathrm{g})$ & $37.1 \pm 5.2$ & $25.7 \pm 1.5^{*}$ & $38.0 \pm 1.2$ & $23.0 \pm 2.2^{*}$ \\
\hline & Mitochondrial protein (g) & $2.09 \pm 0.4$ & $1.58 \pm 0.1^{*}$ & $2.85 \pm 0.3$ & $1.41 \pm 0.2^{*}$ \\
\hline
\end{tabular}

Organs were sampled from offspring born to unshorn and shorn sheep that consumed either $100 \%$ (controls, C ( $n=7-9)$ ) or $50 \%$ (nutrient-restricted, NR ( $n=7-9)$ ) of total metabolisable energy requirements to maintain maternal metabolism and fetal growth between 110 days gestation and term. Values are means \pm S.E.M.; * denotes a significant effect of NR; whilst different superscript letters denote statistically significant differences between shorn and unshorn groups; $P<0.05$.

(Mostyn et al. 2003). Interestingly, the rate of loss of VDAC up to 30 days of age was delayed in NR offspring that could be indicative of an extended period of alveolarisation in these animals. These different adaptations were accompanied by the maintenance of cytochrome $c$ in offspring born to nulliparous mothers, irrespective of the maternal diet. Cytochrome $c$ was shown to be located within the bronchioles where it may have an important role with regard to energy conversion (Kirk \& Strange 1998). The extent to which these adaptations may impact on lung function remains to be established but, as discussed below, could be relevant to the previously established effects of MCE on later breathing control (Symonds et al. 1993).

MCE caused an increase in VDAC abundance in the lung that was maintained up to 1 month of age and is coincident with the time at which the metabolic stimulus to breathing begins to decline (Andrews et al. 1989b). It is associated with a decrease in breathing frequency and a concomitant rise in the recruitment of laryngeal braking (Symonds et al. 1993), the function of which is to extend expiratory time, thereby increasing the time for gaseous exchange within the lung (Andrews et al. 1989a) and potentially increasing energy requirements (Symonds et al. 1993). Differences in mitochondrial protein responses within the lungs over the period in which there are rapid changes in function are, therefore, not unexpected and are consistent with the very different endocrine regulation of UCP and VDAC during fetal and postnatal development (Gnanalingham et al. 2005f).

\section{The kidney}

In the kidney both VDAC and cytochrome $c$ shared the same cellular localisation namely the tubules. These two

Table 4 Effect of maternal cold exposure and nutrient restriction on organ weight, total protein and mitochondrial protein on day 30 of postnatal life.

\begin{tabular}{|c|c|c|c|c|c|}
\hline & & \multicolumn{2}{|c|}{ Unshorn } & \multicolumn{2}{|c|}{ Shorn } \\
\hline & & $\mathrm{C}(n=9)$ & $\mathrm{NR}(n=9)$ & $\mathrm{C}(n=7)$ & $\mathrm{NR}(n=7)$ \\
\hline \multirow[t]{5}{*}{ Lung } & Fresh weight (g) & $262 \pm 15.3$ & $246 \pm 9.3$ & $260 \pm 7.7$ & $261 \pm 9.6$ \\
\hline & Lung:bodyweight ratio & $17.0 \pm 1.6$ & $16.5 \pm 1.3$ & $15.2 \pm 0.9$ & $15.6 \pm 1.1$ \\
\hline & Dry weight (g) & $56 \pm 2.7$ & $48 \pm 1.8$ & $51 \pm 1.8$ & $52 \pm 2.4$ \\
\hline & Total protein (g) & $33.2 \pm 1.9$ & $29.8 \pm 1.0$ & $31.6 \pm 1.3$ & $33.5 \pm 2.3$ \\
\hline & Mitochondrial protein (g) & $0.53 \pm 0.10$ & $0.68 \pm 0.10$ & $0.75 \pm 0.12$ & $0.69 \pm 0.07$ \\
\hline \multirow{4}{*}{ Kidney } & Weight (g) & $42 \pm 1.7^{\mathrm{a}}$ & $39 \pm 1.7^{*}$ & $49 \pm 1.2^{\mathrm{b}}$ & $43 \pm 1.6^{*}$ \\
\hline & Kidney:bodyweight ratio & $2.0 \pm 0.1^{\mathrm{a}}$ & $2.0 \pm 0.1$ & $2.6 \pm 0.2^{\mathrm{b}}$ & $2.3 \pm 0.1$ \\
\hline & Total protein (g) & $10.3 \pm 0.3$ & $9.9 \pm 0.5$ & $11.1 \pm 0.5$ & $10.3 \pm 0.6$ \\
\hline & Mitochondrial protein (g) & $0.82 \pm 0.10^{\mathrm{a}}$ & $1.02 \pm 0.10^{\mathrm{a}}$ & $1.18 \pm 0.04^{\mathrm{b}}$ & $1.15 \pm 0.10^{b}$ \\
\hline \multirow[t]{4}{*}{ Liver } & Weight (g) & $373 \pm 22.7^{\mathrm{a}}$ & $366 \pm 11.7^{\mathrm{a}}$ & $437 \pm 25.5^{b}$ & $414 \pm 21.7^{b}$ \\
\hline & Liver:bodyweight ratio & $23.6 \pm 2.5$ & $24.4 \pm 3.0$ & $25.2 \pm 1.7$ & $24.7 \pm 2.1$ \\
\hline & Total protein (g) & $109 \pm 7.3$ & $108 \pm 5.1$ & $122 \pm 5.5$ & $115 \pm 5.6$ \\
\hline & Mitochondrial protein (g) & $6.0 \pm 0.84$ & $5.4 \pm 0.70$ & $7.1 \pm 0.52$ & $5.4 \pm 0.54$ \\
\hline
\end{tabular}

Organs were sampled from offspring born to unshorn and shorn sheep that consumed either $100 \%$ (controls, C ( $n=7-9$ )) or $50 \%$ (nutrient-restricted, NR $(n=7-9)$ ) of total metabolisable energy requirements to maintain maternal metabolism and fetal growth between 110 days gestation and term. Values are means \pm s.E.M.; * denotes a significant effect of NR; whilst different superscript letters denote statistically significant differences between shorn and unshorn groups; $P<0.05$. 

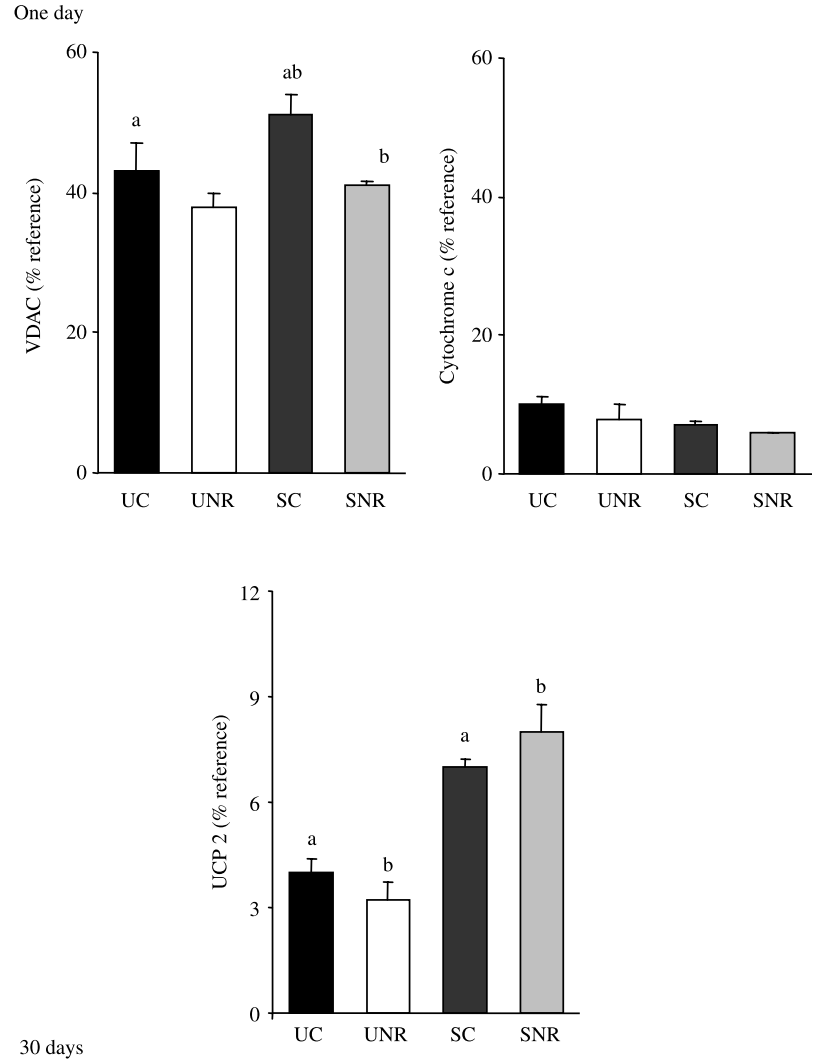

30 days
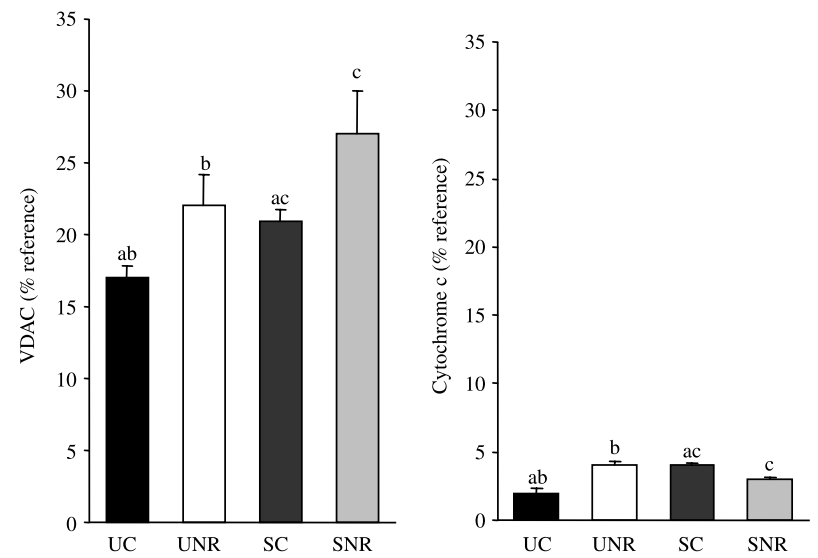

Figure 4 Effects of maternal cold exposure induced from mid-gestation and nutrient restriction during late gestation on the abundance of the mitochondrial proteins voltage-dependent anion channel (VDAC), cytochrome $c$ and uncoupling protein (UCP)2 in the postnatal sheep lung. Mitochondria were prepared from lungs sampled from 1- or 30-day-old offspring born to unshorn (US) and shorn ( $\mathrm{S}$ i.e. cold-exposed) sheep that consumed either $100 \%$ (controls, C) or $50 \%$ (nutrient-restricted, NR) of total metabolisable energy requirements to maintain maternal metabolism and fetal growth between 110 days gestation and term. Values are means with their standard errors; $n=7-9$ per group and the same superscript letters denote statistically significant differences between groups, $P<0.05$.

proteins did, however, show different developmental responses in that a persistent down-regulation of VDAC occurred in offspring born to either nulliparous or coldexposed mothers that was only accompanied with
One day
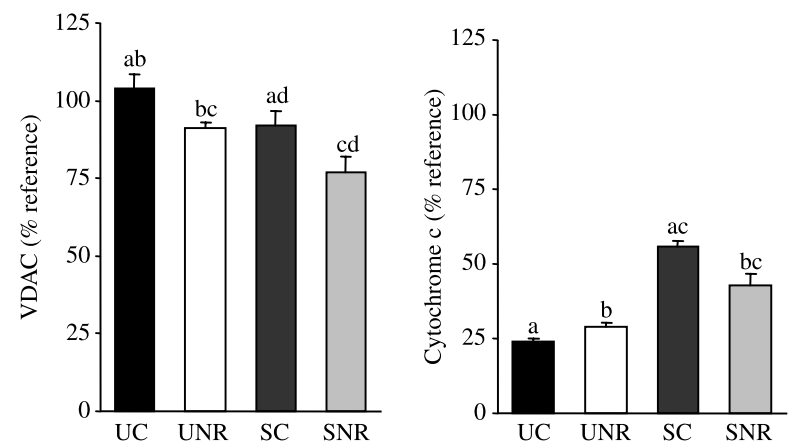

30 days
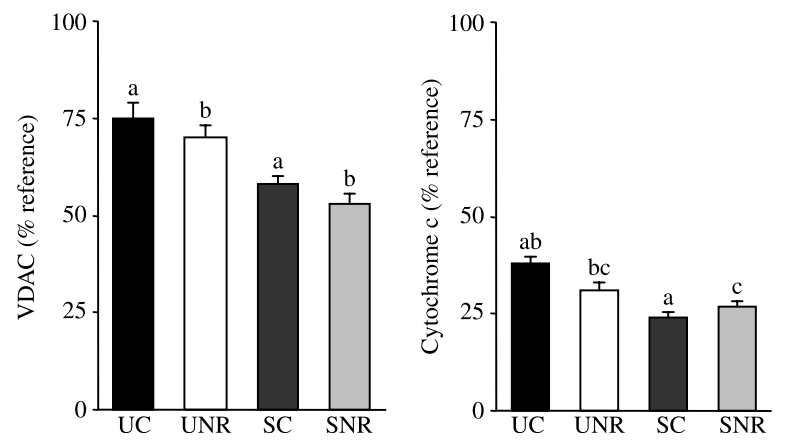

Figure 5 Effects of maternal cold exposure induced from mid-gestation and nutrient restriction during late gestation on the abundance of voltage-dependent anion channel (VDAC) and cytochrome $c$ in the postnatal sheep kidney. Mitochondria were prepared from kidneys sampled from 1- or 30-day-old offspring born to unshorn (US) and shorn (S i.e. cold-exposed) sheep that consumed either 100\% (controls, C) or $50 \%$ (nutrient-restricted, NR) of total metabolisable energy requirements to maintain maternal metabolism and fetal growth between 110 days gestation and term. Values are means with their standard errors; $n=7-9$ per group and the same superscript letters denote statistically significant differences between groups, $P<0.05$.

increased cytochrome $c$ in the latter group. At the same time, VDAC abundance decreased with postnatal age in all groups. Decreased renal VDAC abundance could relate to the reduction in kidney metabolism that would be expected to accompany the fall in overall metabolic rate with increased age (Symonds et al. 1989b). Indeed, an explanation for a reduced metabolic rate in offspring of nulliparous compared with multiparous mothers would be an accelerated loss of UCP1 in their brown adipose tissue (Symonds et al. 2004), the major source of additional heat production at birth (Clarke et al. 1997a) and, therefore, likely to impact on metabolic rate over the first month of life (Symonds et al. 1989b).

The major hormones that regulate mitochondrial protein abundance in adipose tissue and the lung during postnatal development are those secreted from the adrenal and thyroid glands (Gnanalingham et al. 2005b, 2006), but their potential impact on mitochondrial development in the kidney has yet to be examined. It is know that maternal NR over the final 


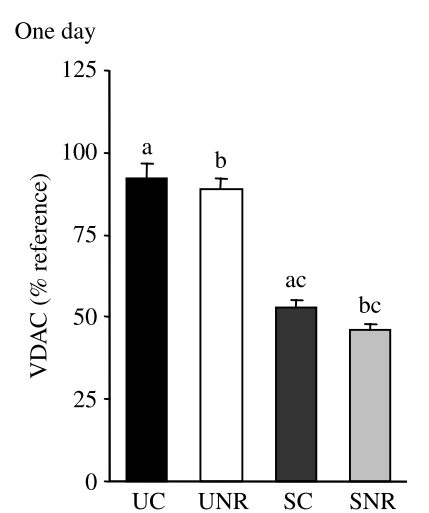

30 days
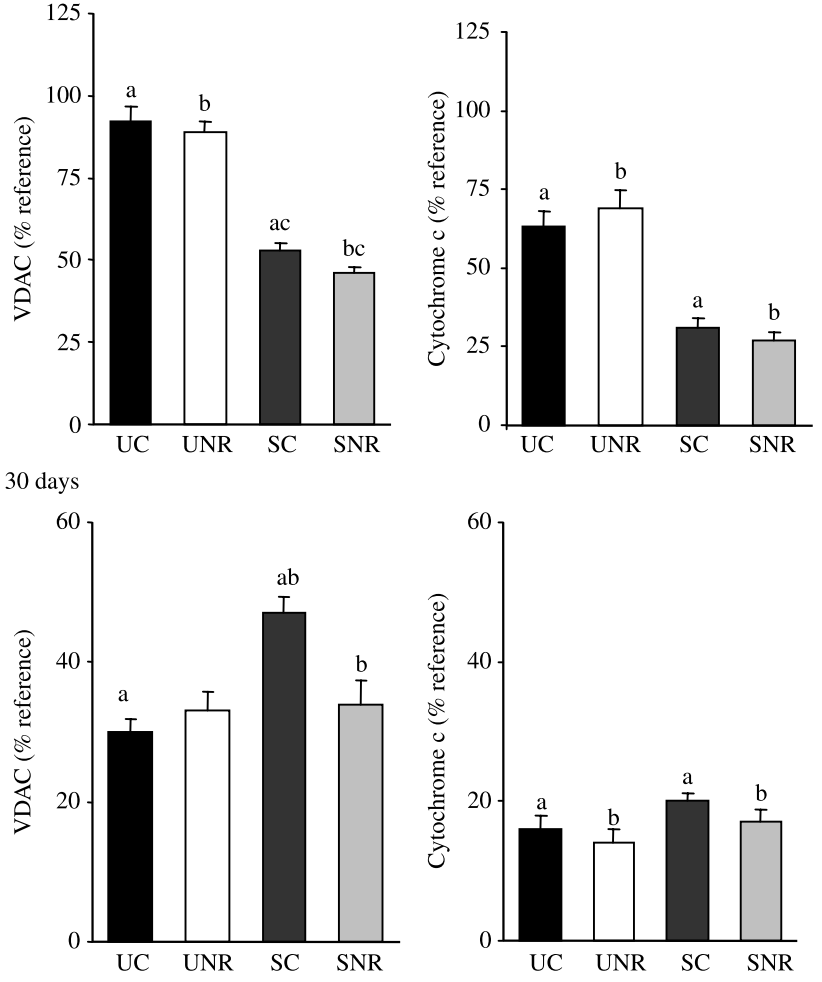

Figure 6 Effects of maternal cold-exposure induced from mid-gestation and nutrient restriction during late gestation on the abundance of voltage-dependent anion channel (VDAC) and cytochrome $c$ in the postnatal sheep liver. Mitochondria were prepared from livers sampled from 1- or 30-day-old offspring born to unshorn (US) and shorn (S i.e. cold-exposed) sheep that consumed either $100 \%$ (controls, C) or $50 \%$ (nutrient-restricted, NR) of total metabolisable energy requirements to maintain maternal metabolism and fetal growth between 110 days gestation and term. Values are means with their standard errors; $n=7-9$ per group and the same superscript letters denote statistically significant differences between groups, $P<0.05$.

month of gestation transiently increases maternal, but not fetal, cortisol (Edwards \& McMillen 2001), although neither maternal parity nor cold exposure have any effect on maternal cortisol (Symonds et al. 1986, 1988a). In contrast, thyroid hormones are raised in cold-exposed mothers (Symonds et al. 1988a) and decrease with parity (Tasende et al. 2002), differences that are maintained through lactation (Symonds et al. 1990). Hypothyroidism has been shown to delay kidney maturation after birth, resulting in decreased renal cortical $\mathrm{Na}^{+} / \mathrm{H}^{+}$transporter activity and brush border membrane NHE-3 protein abundance (Baum et al. 1998), blunted maturational increase in both $\mathrm{Na}^{+} / \mathrm{H}^{+}$and $\mathrm{Cl}^{-} / \mathrm{OH}^{-}$exchange activity (Shah et al. 2000), and lower rates of sodiumdependent proton secretion (Gupta et al. 2004). Differences in maternal and neonatal plasma thyroid hormone concentrations may, therefore, contribute to the maternal effects on mitochondrial protein abundance in the kidney we have found that appear to be confined to the tubular region. (a) Kidney (x 400 magnification)

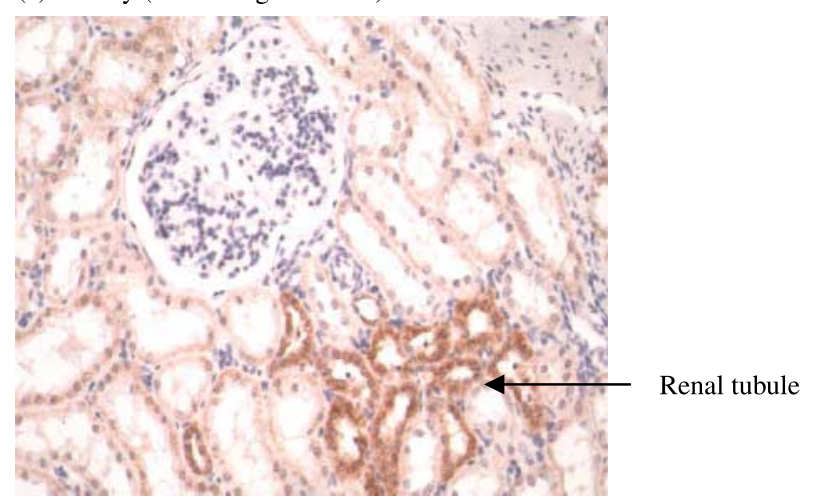

(b) Liver (x 200 magnification)

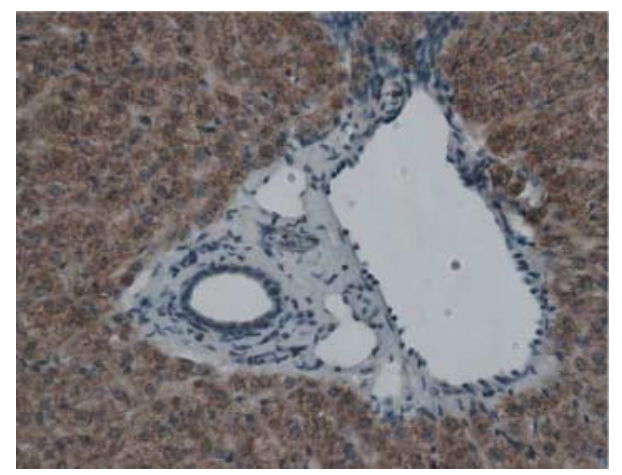

(c) Lung - Voltage dependent anion channel (x 400 magnification)

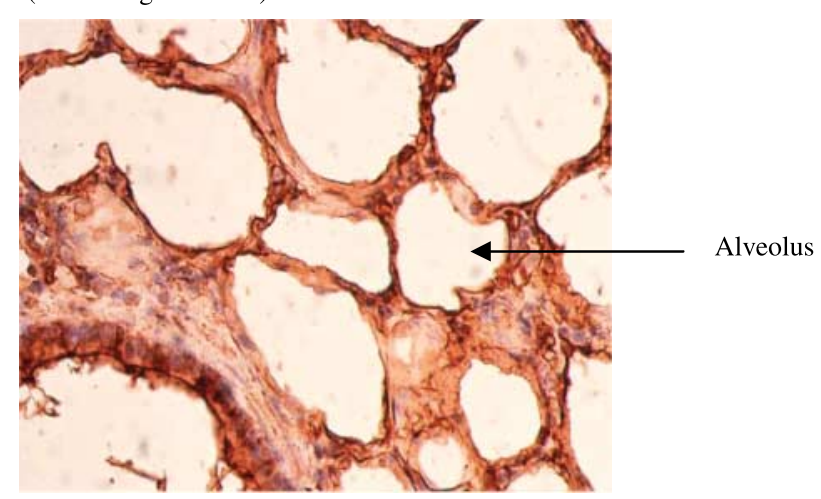

-Cytochrome c (x 200 magnification)

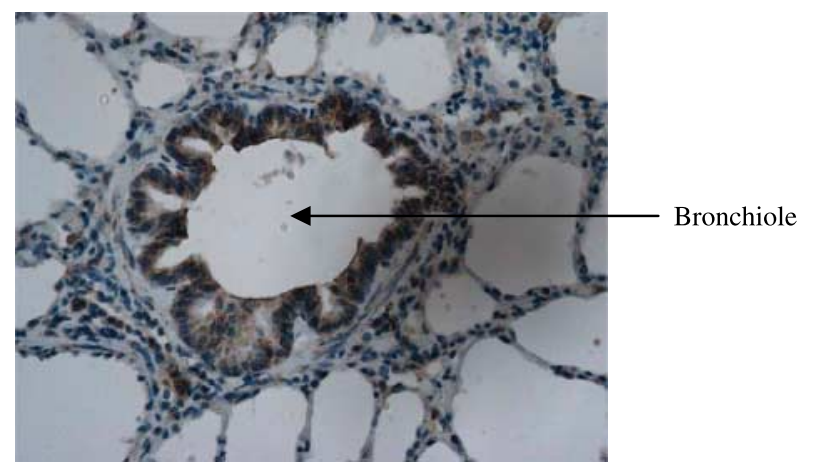

Figure 7 Representative images showing immunocytochemical detection of cytochrome $c$ in the adult sheep (a) kidney and (b) liver and for voltage-dependent anion channel (VDAC) and cytochrome $c$ in adult the (c) lung. 


\section{The liver}

In the liver, both VDAC and cytochrome $c$ shared the same cellular localisation namely the epithelial lining. Hepatic VDAC and cytochrome $c$ abundance was downregulated in offspring of both nulliparous and coldexposed mothers, adaptations that persisted up to 1 month of age only in the offspring of nulliparous mothers. These adaptations were unrelated to liver mass and composition, or maternal diet and, in the case of VDAC, are consistent with the reduced renal abundance found in these offspring, suggesting a common endocrine regulation. The persistent decrease in hepatic VDAC and cytochrome $c$ abundance of offspring born to nulliparous mothers may relate to a lower organ and/or whole body metabolic rate, as discussed above for the kidney. In addition, it may relate to hepatic gluconeogenic potential, which has an appreciable energy demand (Lemasters \& Holmuhamedov 2006) and is raised in cold-exposed mothers (Symonds et al. 1988b). Furthermore, the transient decrease in hepatic VDAC and cytochrome $c$ abundance in cold-exposed offspring may be due to accelerated loss of these proteins around the time of birth, as both were significantly greater than in controls by 1 month of age.

In conclusion, adaptations in the maternal metabolic environment that act to promote or restrict fetal growth from mid-gestation have pronounced effects on the expression and abundance of mitochondrial VDAC, cytochrome $c$ in the kidney, liver and lung, and UCP2 in the lung of neonatal sheep. Interestingly, these adaptations are largely similar between offspring of nulliparous mothers and those born to mothers, who were chronically cold-exposed, suggesting that common mechanisms unrelated to whole body or organ growth are involved. Future studies aimed at elucidating the effects on the maternal and fetal thyroid hormone and cortisol axis under these different conditions would be predicted to further define the precise mechanisms involved. This may be important, particularly in infants whose growth is restricted or enhanced, as optimising mitochondrial function in the newborn may promote metabolic adaptation at birth.

\section{Acknowledgements}

D P Yakubu was supported by a University of Nottingham International Office Studentship and a Commonwealth Scholarship Commission in the United Kingdom and a Travel Award from the Physiological Society. The authors declare that there is no conflict of interest that would prejudice the impartiality of this scientific work.

\section{References}

Agricultural Research Council 1980 Requirements for energy, The Nutritional Requirements of Ruminant Livestock, Slough, UK: Commonwealth Agricultural Bureau, pp 115-119.
Andrews DC, Symonds ME \& Johnson PJ 1989a The interaction of the upper airway and the thermometabolism on respiratory rhythm during non-rapid eye movement sleep in the developing lamb. Journal of Developmental Physiology 16 37-43.

Andrews DC, Symonds ME \& Johnson PJ 1989 $b$ Thermoregulation and the control of breathing during non-rapid eye movement sleep in the developing lamb. Journal of Developmental Physiology 16 27-36.

Arsenijevic D, Onuma H, Pecquer C, Raimbault S, Manning BS, Miroux B, Couplan E, Alves-Guerra M-C, Goubern M, Surwit R, et al. 2000 Disruption of the uncoupling protein-2 gene in mice reveals a role in immunity and reactive oxygen species production. Nature Genetics 26 435-439.

Baum M, Dwarakanath V, Alpern RJ \& Moe OW 1998 Effects of thyroid hormone on the neonatal renal cortical $\mathrm{Na}^{+} / \mathrm{H}^{+}$antiporter. Kidney International 53 1254-1258.

Budge H, Bispham J, Dandrea J, Evans L, Heasman L, Ingleton P, Sullivan C, Wilson V, Stephenson T \& Symonds ME 2000 Effect of maternal nutrition on brown adipose tissue and prolactin receptor status in the fetal lamb. Pediatric Research 47 781-786.

Buemann B, Schierning B, Toubro S, Bibby BM, Sørensen T, Dalgaard L, Pedersen O \& Astrup A 2001 The association between the val/ala-55 polymorphism of the uncoupling protein 2 gene and exercise efficiency. International Journal of Obesity 25 467-471.

Clarke L, Heasman L, Firth K \& Symonds ME 1997a Influence of route of delivery and ambient temperature on thermoregulation in newborn lambs. American Journal of Physiology 272 R1931-R1939.

Clarke L, Buss DS, Juniper DS, Lomax MA \& Symonds ME 1997b Adipose tissue development during early postnatal life in ewe-reared lambs. Experimental Physiology 82 1015-1017.

Colombini M 1979 A candidate for the permeability pathway of the outer mitochondrial membrane. Nature 279 643-645.

Crompton M 1999 The mitochondrial permeability transition pore and its role in cell death. Biochemical Journal 341 233-249.

Dandrea J, Wilson V, Gopalakrishnan G, Heasman L, Budge H, Stephenson T \& Symonds ME 2001 Maternal nutritional manipulation of placental growth and glucose transporter-1 abundance in sheep. Reproduction 122 793-800.

Edwards LJ \& McMillen IC 2001 Maternal undernutrition increases arterial blood pressure in the sheep fetus during late gestation. Journal of Physiology 533 561-570.

Erlanson-Albertsson C 2003 The role of uncoupling proteins in the regulation of metabolism. Acta Physiologica Scandinavia 178 405-412.

Fowden AL, Li J \& Forhead AJ 1998 Glucocorticoids and the preparation for life after birth: are there long-term consequences of the life insurance? Proceedings of the Nutrition Society $\mathbf{5 7}$ 113-122.

Gardner DS, Buttery PJ, Daniel Z \& Symonds ME 2007 Factors affecting birth weight in sheep: maternal environment. Reproduction 133 297-307.

Gnanalingham MG, Mostyn A, Symonds ME \& Stephenson T 2005a Ontogeny and nutritional programming of adiposity: potential role of glucocorticoid sensitivity and uncoupling protein-2. American Journal of Physiology 289 R1407-R1415.

Gnanalingham MG, Mostyn A, Gardner DS, Stephenson T \& Symonds ME 2005b Developmental regulation of adipose tissue: nutritional manipulation of local glucocorticoid action and uncoupling protein 2. Adipocytes 1 221-228.

Gnanalingham MG, Mostyn A, Dandrea J, Yakubu DP, Symonds ME \& Stephenson T 2005c Ontogeny and nutritional programming of uncoupling protein-2 and glucocorticoid receptor mRNA in the ovine lung. Journal of Physiology 565 159-169.

Gnanalingham MG, Mostyn A, Forehead AJ, Fowden AL, Symonds ME \& Stephenson T 2005d Increased uncoupling protein-2 mRNA abundance and glucocorticoid sensitivity in adipose tissue in the sheep fetus during late gestation is dependent on plasma cortisol and triiodothyronine. Journal of Physiology 567 283-292.

Gnanalingham MG, Giussani DA, Sivathondan P, Forehead AJ, Stephenson T, Symonds ME \& Gardner DS 2005e Chronic umbilical 
cord compression results in premature maturation of lung and brown adipose tissue in the late gestation ovine fetus. American Journal of Physiology 289 E456-E465.

Gnanalingham MG, Mostyn A, Webb R, Keisler DH, Raver N, AlvesGuerra MC, Pecqueur C, Miroux B, Symonds ME \& Stephenson T $2005 f$ Differential effects of leptin administration on the abundance of uncoupling protein-2 and glucocorticoid action during neonatal development. American Journal of Physiology 289 E1093-E1100.

Gnanalingham MG, Mostyn A, Gardner DS, Stephenson T \& Symonds ME 2006 Developmental regulation of the lung in preparation for life after birth: nutritional manipulation of local glucocorticoid action and uncoupling protein 2. Journal of Endocrinology 188 375-386.

Gupta N, Dwarakanath V \& Baum M 2004 Maturation of the $\mathrm{Na}^{+} / \mathrm{H}^{+}$ antiporter (NHE3) in the proximal tubule of the hypothyroid adrenalectomized rat. American Journal of Physiology 287 F521-F217.

Kirk K \& Strange K 1998 Functional properties and physiological roles of organic solute channels. Annual Review of Physiology 60 719-739.

Lemasters JJ \& Holmuhamedov E 2006 Voltage-dependent anion channel (VDAC) as mitochondrial governator - thinking outside the box. Biochemica et Biophysica Acta 1762 181-190.

Lowry OH, Rosenbrough NJ, Farr AL \& Randall RJ 1951 Protein measurement with the Folin phenol reagent. Journal of Biological Chemistry 193 265-275.

McEnery MW, Dawson TM, Verma A, Gurley D, Colombini M \& Snyder SH 1993 Mitochondrial voltage-dependent anion channel. Immunochemical and immunohistochemical characterization in rat brain. Journal of Biological Chemistry 268 23289-23296.

Mellor DJ \& Cockburn F 1986 A comparison of energy metabolism in the new-born infant, piglet and lamb. Quarterly Journal of Experimental Physiology 71 361-379.

Mostyn A, Wilson V, Dandrea J, Yakubu DP, Budge H, AlvesGuerra MC, Pecqueur C, Miroux B, Symonds ME \& Stephenson T 2003 Ontogeny and nutritional manipulation of mitochondrial protein abundance in adipose tissue and the lungs of postnatal sheep. British Journal of Nutrition 90 323-328.

Mostyn A, Pearce S, Stephenson T \& Symonds ME 2004 Hormonal and nutritional regulation of adipose tissue mitochondrial development and function in the newborn. Experimental and Clinical Endocrinology and Diabetes 112 2-9.

Negre-Salvayre A, Hirtz C, Carrera G, Cazenave R, Troly M, Salvayre R, Penicaud L \& Casteilla L 1997 A role for uncoupling protein-2 as a regulator of mitochondrial hydrogen peroxide generation. FASEB Journal 11 809-815.

Pearce S, Budge H, Mostyn A, Korur N, Wang J, Ingleton PM, Symonds ME \& Stephenson T 2005 Differential effects of maternal cold exposure and nutrient restriction on prolactin receptor and uncoupling protein 1 abundance in adipose tissue during development in young sheep. Adipocytes 1 57-64.

Pecqueur C, Alves-Guerra M-C, Gelly C, Lévi-Meyrueis C, Couplan E, Collins S, Ricquier D, Bouillaud F \& Miroux B 2001 Uncoupling protein-2: in vivo distribution, induction upon oxidative stress and evidence for translational regulation. Journal of Biological Chemistry 276 8705-8712.

Rousset S, Alves-Guerra M-C, Ouadghiri-Bencherif S, Kozak LP, Miroux B, Richard D, Bouillaud F, Ricquier D \& Cassard-Doulcier A-M 2003 UCP2 is expressed in the female mice reproductive tract whereas UCP1 is not. Journal of Biological Chemistry 278 45843-45847.

Shah M, Quigley R \& Baum M 2000 Maturation of proximal straight tubule $\mathrm{NaCl}$ transport: role of thyroid hormone. American Journal of Physiology 278 F596-F602.
Stuart JA, Harper JA, Brindle KM, Jekabsons MB \& Brand MD 2001 Physiological levels of mammalian uncoupling protein 2 do not uncouple yeast mitochondria. Journal of Biological Chemistry $\mathbf{2 7 6}$ 18633-18639.

Symonds ME 1995 Pregnancy, parturition and neonatal development interactions between nutrition and thyroid hormones. Proceedings of the Nutrition Society 54 329-343.

Symonds ME, Bryant MJ \& Lomax MA 1986 The effect of shearing on the energy metabolism of the pregnant ewe. British Journal of Nutrition 56 635-643.

Symonds ME, Bryant MJ \& Lomax MA 1988a Metabolic adaptation during pregnancy in winter-shorn sheep. Journal of Agricultural Science 111 137-145.

Symonds ME, Bryant MJ, Shepherd DA \& Lomax MA 1988b Glucose metabolism in shorn and unshorn pregnant sheep. British Journal of Nutrition 60 249-263.

Symonds ME, Andrews DC \& Johnson PJ 1989a The endocrine and metabolic response to feeding in the developing lamb. Journal of Endocrinology 123 295-302.

Symonds ME, Andrews DC \& Johnson PJ 1989b The control of thermoregulation in the developing lamb during slow wave sleep. Journal of Developmental Physiology 11 289-298.

Symonds ME, Bryant MJ \& Lomax MA 1990 Metabolic adaptation during lactation in winter-shorn sheep. Journal of Agricultural Science 114 201-205.

Symonds ME, Bryant MJ, Clarke L, Darby CJ \& Lomax MA 1992 Effect of maternal cold exposure on brown adipose tissue and thermogenesis in the neonatal lamb. Journal of Physiology 455 487-502.

Symonds ME, Lomax MA, Kenward MG, Andrews DC \& Johnson PJ 1993 Effect of the prenatal maternal environment on the control of breathing during non-rapid eye movement sleep in the developing lamb. Journal of Developmental Physiology 19 43-50.

Symonds ME, Bird JA, Clarke L, Gate JJ \& Lomax MA 1995 Nutrition, temperature and homeostasis during perinatal development. Experimental Physiology 80 907-940.

Symonds ME, Pearce S, Bispham J, Gardner DS \& Stephenson T 2004 Timing of nutrient restriction and programming of fetal adipose tissue development. Proceedings of the Nutrition Society 63 397-403.

Tasende C, Meikle A, Rodriguez-Pinon M, Forsberg M \& Garofalo EG 2002 Estrogen and progesterone receptor content in the pituitary gland and uterus of progesterone-primed and gonadotropin releasing hormone-treated anestrous ewes. Threiogenology 57 1719-1731.

Tu N, Chen H, Winnikes U, Reinert I, Marmann G, Pirke KM \& Lentes KU 1999 Molecular cloning and functional characterization of the promoter region of the human uncoupling protein-2 gene. Biochemical and Biophysical Research Communications 265 326-334.

Voehringer DW, Hirschberg DL, Xiao J, Lu Q, Roederer M, Lock CB, Herzenberg LA, Steinman L, Herzenberg LA, Steinman L \& Herzenberg LA 2000 Gene microarray identification of redox and mitochondrial elements that control resistance or sensitivity to apoptosis. PNAS 97 2680-2685.

Xiao H, Massaro D, DeCarlo Massaro G \& Clerch LB 2004 Expression of lung uncoupling protein-2 mRNA is modulated developmentally and by caloric intake. Experimental Biology and Medicine 229 479-485.

Zalk R, Israelson A, Garty ES, Azoulay-Zohar H \& Shoshan-Barmatz V 2005 Oligomeric states of the voltage-dependent anion channel and cytochrome $c$ release from mitochondria. Biochemical Journal 386 73-83.

Received 14 September 2006

First decision 30 October 2006

Accepted 30 November 2006 